\title{
THE RELATIONSHIPS BETWEEN SELF-REPORTED HEALTH STATUS AND SUBJECTIVE HEALTH LITERACY AMONG YOUNG ADULTS IN LITHUANIA
}

\author{
Jurate Cesnaviciene \\ Lithuanian University of Educational Sciences, Lithuania \\ Stase Ustilaite \\ Lithuanian University of Educational Sciences, Lithuania \\ Ausra Kalinkeviciene \\ Lithuanian University of Educational Sciences, Lithuania
}

\begin{abstract}
Seeking to successfully act in the 21st century, a person should have a relatively big spectrum of abilities and competences; in other words, s/he should develop literacy in a number of spheres. Health literacy is essential for a person's daily capability to manage own health and the quality of life, which is dependent on it. It is significant for the social and economic development of the society. The purpose of the research was to identify the relationships between subjective health literacy and self-reported health status among young adults in Lithuania. The methods of the research included the analysis, interpretation and generalisation of scientific literature on the topic of research, as well as anonymous questionnaire survey. Self-reported health status was ascertained by a single WHO recommended question: "How is your health in general?" Subjective health literacy of young adults was measured using an HLS-EU-Q-47 questionnaire. The survey was conducted in 2014. The research sample included 798 young adults. The results showed high correlation between health literacy in the three health relevant areas and general health literacy. Having generalised the research data, it was noted that the young adults with good/very good selfreported health status tend to achieve sufficient or excellent levels of health literacy on health care, disease prevention or health promotion and general health literacy.
\end{abstract}

Keywords: health literacy, HLS-EU-Q-47 questionnaire, self-reported health status, young adults.

\section{Introduction}

The comprehensive European health policy framework "Health 2020" (2013) is based on the idea that health is a fundamental resource for the human, social and economic development and the future of Europe. Health is determined by heredity (genetics), health care services, physical and social environment; however, lifestyle has the greatest impact on health (Lalonde, 1974). Health literacy is an important empowerment tool, which helps every person to assume greater responsibility for own health and choose health- 
enhancing behaviours. This concept has been receiving considerable attention of researchers of different countries since the last decade of the 20th century. The systematic review of scientific literature on health literacy has demonstrated a strong association between the levels of health literacy and self-reported health status and health outcomes (Dewalt et al., 2004; von Wagner et al., 2007; Berkman et al., 2011; HLS-EU Consortium, 2012; Sentell et al., 2014; Mottus et al., 2014), as well as lifestyle (von Wagner et al., 2007). However, there is a lack of sufficient research in Lithuania. Two more exhaustive studies publicised in the Lithuanian language can be mentioned: D. Zagurskiene "The Evaluation of Patients' Health Literacy" (2009) and Z. Javtokas "Overview of the Research Data on Health Literacy of Lithuanian Population" (2012). However, the aforesaid studies do not reveal the connections between the respondents' health literacy and self-reported health status. Therefore, it is relevant to investigate health literacy of Lithuanian youth and its connections to self-reported health status.

The object of the research: subjective health literacy and self-reported health status.

The purpose of the research: was to identify there lationships between subjective health literacy and self-reported health status among young adults in Lithuania.

The methods of the research: the analysis, interpretation and generalisation of scientific literature on the topic of the research, anonymous questionnaire survey.

\section{The Multidimensional Concept of Health Literacy}

The interdisciplinary concept "health literacy" was first mentioned in scientific literature by S. Simonds (1974). He discussed health education as one of the trends of social policy, highlighted its significance in the sectors of education and health protection and in the media, as well as defined education standards in the sphere of health education that were compulsory to achieve for all learners. In the first scientific publications, the conception of health literacy was presented as a person's ability to fulfil tasks related to information about health that demanded reading and arithmetic skills (Parker et al., 1995; Williams et al., 1995). However, this narrow approach changed in the course of time.

The definition of health literacy most frequently cited in scientific research carried out in the field of healthcare is the one provided by American Medical Association (1999), which reflects medical approach: "health literacy is the constellation of skills, including the ability to perform basic reading and numeral tasks required to function in the healthcare environment". World Health Organization (WHO, 1998, 10) proposes a definition that is most often used in 
the context of public health on the international scale and is one of the most acknowledged definitions of health literacy, "which determines the motivation and ability of individuals to gain access to, understand and use information in ways which promote and maintain good health". Referring to this conception and perceiving health literacy as an outcome of health education and public health, D. Nutbeam (2000) distinguishes its three levels: basic/functional literacy, communicative/interactive literacy, and critical literacy. These three types of health literacy characterize the application of skills for functioning in everyday situations (functional health literacy), to more advanced literacy and cognitive skills that can be used to effectively participate in everyday activities and apply new information to changing circumstances (interactive or communicative health literacy). Hence, different levels of health literacy demonstrate a person's growing autonomy and enable his/her understanding, critical analysis and evaluation of the information related to health, as well as refer to it when making health-promoting decisions.

The new conception of health literacy is based on the systemic analysis and critical review of definitions and conceptual models provided in scientific literature: "Health literacy is linked to literacy and entails people's knowledge, motivation and competences to access, understand, appraise, and apply health information in order to make judgments and take decisions in everyday life concerning healthcare, disease prevention and health promotion to maintain or improve quality of life during the life course" (Sørensen et al., 2012, 3). It should be emphasised that the provided conception of health literacy also includes functional, interactive and critical health literacy introduced by D. Nutbeam (2000). In the context of public health, the multidimensional concept of health literacy reflects a complex approach that combines three health relevant areas (health care, disease prevention, health promotion) and four information processing stages (access, understand, appraise, apply). The new conception is visualised by the integrated model of health literacy, which shows the connections of health literacy with health service use, health behaviour, equity and participation in activities that enable the promotion of individual or public health on both the individual level and the population level. Moreover, attention is paid to personal determinants (e.g. age, gender, race, socioeconomic status, education, occupation, employment, income, literacy), situational determinants (e.g. family and peer influences, social support, media use and physical environment), as well as societal and environmental determinants (e.g. demographic situation, language, culture, societal systems, political forces) that condition health literacy (Sørensen et al., 2012). 
Jurate Cesnaviciene, Stase Ustilaite, Ausra Kalinkeviciene. The Relationships Between SelfReported Health Status and Subjective Health Literacy Among Young Adults in Lithuania

\section{Research Methodology}

An anonymous paper-and-pencil questionnaire and online questionnaire were used in the survey. The survey was carried out in 2014.

The research instrument. Demographic characteristics measured via the questionnaire included age (year) and gender (male, female). Self-reported health status was ascertained by a single question (How is your health in general?), to which participants had five response options: very good, good, fair, bad and very bad. This question is a version recommended by WHO as a standard measurement of self-reported health in European populations (de Bruin et al., 1996). Subjective health literacy was measured using an HLS-EU-Q-47 questionnaire (HLS-EU consortium, 2012). Respondents were asked to report on 47 items using a 4-point Likert scale (very difficult, difficult, easy, and very easy). The "don't know" answer option was used when stated spontaneously and coded as a missing value.

With the agreement of the HLS-EU Project coordinator K. Sørensen, the HLS-EU-Q-47 questionnaire was translated from English into the Lithuanian language using the translation-back-translation method. The questionnaire was pre-tested for comprehension and completeness. To explore internal consistency of the questionnaire, Cronbach's $\alpha$ was calculated. The analysis showed that Cronbach's $\alpha$ was satisfactory (Cronbach's $\alpha=0.94$ respectively).

Health literacy index scores were standardized on a metric scale between 0 and 50 and constructed using the formula (HLS-EU consortium, 2012):

$$
\mathrm{I}=(\mathrm{X}-1) \times \frac{50}{3}
$$

where: I - health literacy index, $\mathrm{X}$ - mean of all participating items for each individual. Four ranges of health literacy were distinguished: inadequate level (0-25), problematic level (>25-33), sufficient level (>33-42) and excellent level (>42-50) of health literacy (HLS-EU consortium, 2012).

Population and sample size. According to the data of the Department of Statistics in Lithuania, there lived 482142 young adults aged 18-29, out of them 247578 males and 234564 females. The research sample was determined using sample size calculator (http://www.surveysystem.com/sscalc.htm). Having conducted calculations, it was determined that 798 respondents (399 males and 399 females) was a sufficient research sample that would represent the general population of 18-29 year old young adults. Table 1 shows the sample characteristics. 
Table 1 Characteristics of research sample

\begin{tabular}{|c|c|c|c|c|c|c|}
\hline \multirow{2}{*}{$\begin{array}{c}\text { Age in } \\
\text { categories }\end{array}$} & \multicolumn{2}{|c|}{ Men $(\mathbf{N}=\mathbf{3 9 9})$} & \multicolumn{2}{c|}{ Women $(\mathbf{N}=\mathbf{3 9 9})$} & \multicolumn{2}{c|}{ Total $(\mathbf{N}=\mathbf{7 9 8})$} \\
\cline { 2 - 7 } & $\mathrm{N}$ & $\%$ & $\mathrm{~N}$ & $\%$ & $\mathrm{~N}$ & $\%$ \\
\hline $18-19$ & 136 & 34,1 & 69 & 17,3 & 205 & 25,7 \\
\hline $20-24$ & 136 & 34,1 & 183 & 45,9 & 319 & 40 \\
\hline $25-29$ & 127 & 31,8 & 147 & 36,8 & 274 & 34,3 \\
\hline
\end{tabular}

The statistical analysis. Statistical analyses were performed using SPSS Statistics version 17.0 for Windows. The following methods were applied to analyse the research data: descriptive analysis (frequencies, percent), Pearson's Chi-Square Tests (nonparametric test that compares two independent samples), Kruskal-Wallis tests (nonparametric test that compares three or more independent samples), Pearson correlation coefficient, p-values less than 0.05 indicate a statistically significant. Cronbach $\alpha$ was used to test the reliability of the questionnaire scores and measure the internal consistency of propositions.

\section{Research Results and Discussion}

Self-reported health status of young adults. Self-reported health is one of the important health indicators. Having generalised the data, it was determined that most research participants defined their health status as good or very good (Table 2).

Table 2 Distribution of young adults by self-reported health status

\begin{tabular}{|c|c|c|c|c|c|c|}
\hline \multirow{2}{*}{$\begin{array}{c}\text { Self-reported } \\
\text { health status }\end{array}$} & \multicolumn{2}{|c|}{ Men $(\mathbf{N}=\mathbf{3 9 9})$} & \multicolumn{2}{c|}{ Women $(\mathbf{N}=\mathbf{3 9 9})$} & \multicolumn{2}{c|}{ Total $(\mathbf{N = 7 9 8 )}$} \\
\cline { 2 - 7 } & $\mathbf{N}$ & $\mathbf{\%}$ & $\mathbf{N}$ & $\mathbf{\%}$ & $\mathbf{N}$ & $\mathbf{\%}$ \\
\hline Very good & 109 & 27.3 & 72 & 18 & 181 & 22.7 \\
\hline Good & 205 & 51.4 & 224 & 56.1 & 429 & 53.8 \\
\hline Fair & 72 & 18 & 95 & 23.8 & 167 & 20.9 \\
\hline Bad & 3 & 0.8 & 6 & 1.5 & 9 & 1.1 \\
\hline Very bad & 10 & 2.5 & 2 & 0.5 & 12 & 1.5 \\
\hline
\end{tabular}

A fifth of respondents indicated that their health was fair, $2.6 \%$ stated that their health was bad or very bad. More men than women identified their health as very bad $\left(\chi^{2}=17.906 ; p<0.001\right)$. The results of our research reflect the general tendencies of self-reported health status of young adults that participated in research of health behaviour among Lithuanian adult population (Grabauskas et al., 2015).

Health literacy of young adults. Self-reported health literacy of young adults was assessed in three health relevant areas: health care, disease prevention, and health promotion. 
Jurate Cesnaviciene, Stase Ustilaite, Ausra Kalinkeviciene. The Relationships Between SelfReported Health Status and Subjective Health Literacy Among Young Adults in Lithuania

Though the majority of young adults had sufficient or excellent abilities to access and understand information on medical or clinical issues, more than a half of the research participants had inadequate or problematic abilities to interpret and evaluate medical information. Such results invite to pay attention to the fact that not all research participants developed abilities of critical thinking. Therefore, they might face difficulties when assessing the retrieved information and its reliability to make health-related decisions. It is presumed that such young adults will also face difficulties when making decisions related to taking care of own or others' health. Thus, having generalised the research results, it is possible to maintain that the majority of the young adults $(60.8 \%)$ were estimated to have problematic or inadequate health literacy on health care (Table 3). Persons with sufficient or excellent levels of health literacy made up $30.3 \%$ and $8.9 \%$ of the total respectively. Having compared the obtained results to the data of European Health Literacy Survey, it was determined that the percentage of young adults having sufficient or excellent levels of health literacy on health care in Lithuania was similar to the percentage of adults that participated in the research in Spain, but less like the percentage of adults in Austria, Bulgaria, Germany, Greece, Ireland, Netherlands and Poland (HLS-EU Consortium, 2012).

Table 3 Distribution of young adults by level of health literacy (\%)

\begin{tabular}{|c|c|c|c|c|}
\hline & $\begin{array}{c}\text { Health literacy } \\
\text { levels }\end{array}$ & $\begin{array}{c}\text { Men } \\
(\mathbf{N = 3 9 9})\end{array}$ & $\begin{array}{c}\text { Women } \\
\mathbf{( N = 3 9 9 )}\end{array}$ & $\begin{array}{c}\text { Total } \\
\mathbf{( N = 7 9 8 )}\end{array}$ \\
\hline \multirow{3}{*}{$\begin{array}{c}\text { Health literacy on } \\
\text { health care }\end{array}$} & Inadequate & 20.8 & 18.5 & 19.7 \\
\cline { 2 - 5 } & Problematic & 39.8 & 42.4 & 41.1 \\
\cline { 2 - 5 } & Sufficient & 30.3 & 30.3 & 30.3 \\
\cline { 2 - 5 } & Excellent & 9 & 8.8 & 8.9 \\
\hline \multirow{3}{*}{$\begin{array}{c}\text { Health literacy on } \\
\text { disease prevention }\end{array}$} & Inadequate & 17 & 14.5 & 15.8 \\
\cline { 2 - 5 } & Problematic & 34.3 & 35.3 & 34.8 \\
\cline { 2 - 5 } & Sufficient & 34.8 & 35.8 & 35.3 \\
\hline \multirow{3}{*}{$\begin{array}{c}\text { Health literacy on } \\
\text { health promotion }\end{array}$} & Excellent & 13.8 & 14.3 & 14 \\
\cline { 2 - 5 } & Inadequate & 21.6 & 23.1 & 22.3 \\
\cline { 2 - 5 } & Problematic & 37.3 & 36.6 & 37 \\
\cline { 2 - 5 } & Sufficient & 29.8 & 30.8 & 30.3 \\
\hline \multirow{3}{*}{ General health literacy } & Excellent & 11.3 & 9.5 & 10.4 \\
\cline { 2 - 5 } & Inadequate & 17.5 & 15.3 & 16.4 \\
\cline { 2 - 5 } & Problematic & 40.6 & 41.4 & 41 \\
\cline { 2 - 5 } & Sufficient & 34.8 & 35.3 & 35.1 \\
\cline { 2 - 5 } & Excellent & 7 & 8 & 7.5 \\
\hline
\end{tabular}


This study showed that more than a half of the research participants had sufficient or excellent abilities to access, understand information on health risk factors and derive meaning. But abilities to interpret and evaluate, to judge the relevance of the information on risk factors were problematic or inadequate. Summing up, few of young adults (14\%) had excellent health literacy on disease prevention. $35.3 \%$ of young adults had sufficient health literacy in this area (Table 3). A half of the research participants (50.6\%) had problematic or inadequate health literacy on disease prevention. It is assumed that these young adults might face difficulties in controlling own health and reducing the risks of environmental factors. They might find it difficult to make decisions and choose such a way of life that would help them avoid contagious or chronic diseases. Therefore, insufficient abilities will affect one's health at later stages of life, especially in the old age, if they are not developed. Having compared the research results with the results of European Health Literacy Survey, it was noted that the percentage of young adults with sufficient or excellent levels of health literacy on disease prevention in Lithuania was similar to the percentage of young people in Austria and Spain, whereas it was greater in comparison to Bulgaria and less like the percentage of adults in Germany, Greece, Ireland, Netherlands and Poland (HLS-EU Consortium, 2012).

Analysing the respondents' replies about health literacy on health promotion (Table 3), it is possible to claim that two-fifths of the young adults had sufficient or excellent health literacy on health promotion. Health literacy of the bigger half of the research participants in the field of health promotion was problematic or inadequate. They lacked the abilities to update oneself on health issues, to understand health-related information and derive meaning, as well as to form a reflected opinion on health issues. Such a level of health literacy is a matter of concern since it is assumed that a lot of the research participants will face difficulties when promoting own health due to the lack of knowledge how to do it. The obtained research results reveal the existing problem in education; though it is common knowledge that "the education sector can help create healthier people and communities by improving health literacy and strengthening essential life skills" (WHO, 2015, p. 1). Nevertheless, not all young people, who have attained general education, are health literate. This promotes risky behaviour among young people.

Having compared the results obtained by European Health Literacy Survey with the Lithuanian survey on health literacy of young adults, it appeared that the percentage of young adults having sufficient or excellent levels of health literacy on health promotion was close to the results obtained in Bulgaria, but less like the percentage of adults in Austria, Bulgaria, Germany, Greece, Spain, Ireland, Netherlands and Poland (HLS-EU Consortium, 2012). 
Jurate Cesnaviciene, Stase Ustilaite, Ausra Kalinkeviciene. The Relationships Between SelfReported Health Status and Subjective Health Literacy Among Young Adults in Lithuania

Having calculated the index of general health literacy of young adults, it was determined that $16.4 \%$ respondents had inadequate, $41 \%$ - problematic, $35.1 \%$ - sufficient and $7.5 \%$ had excellent general health literacy. The obtained data were similar to the ones obtained in Austria, Bulgaria and Spain (HLS-EU Consortium, 2012). However, the number of Lithuanian young adults that were characterised by sufficient or excellent levels of health literacy was lower than in Germany, Greece, Ireland, Netherlands and Poland (HLS-EU Consortium, 2012).

The results of research on Lithuanian young adults showed high correlation between general health literacy and health literacy in the three health relevant areas (Table 4).

Table 4 Correlations between general health literacy and health literacy in three health relevant areas

\begin{tabular}{|l|c|c|c|c|}
\hline & $\begin{array}{c}\text { Health } \\
\text { literacy on } \\
\text { health care }\end{array}$ & $\begin{array}{c}\text { Health literacy } \\
\text { on disease } \\
\text { prevention }\end{array}$ & $\begin{array}{c}\text { Health literacy } \\
\text { on health } \\
\text { promotion }\end{array}$ & $\begin{array}{c}\text { General health } \\
\text { literacy }\end{array}$ \\
\hline $\begin{array}{l}\text { Health literacy on } \\
\text { health care }\end{array}$ & $\mathrm{r}=0.628^{* *}$ & $\mathrm{r}=0.584^{* *}$ & $\mathrm{r}=0.819^{* *}$ \\
\hline $\begin{array}{l}\text { Health literacy on } \\
\text { disease prevention }\end{array}$ & & $\mathrm{r}=0.741^{* *}$ & $\mathrm{r}=0.918^{* *}$ \\
\hline $\begin{array}{l}\text { Health literacy on } \\
\text { health promotion }\end{array}$ & & & $\mathrm{r}=0.880^{* *}$ \\
\hline
\end{tabular}

Note: $r$ - Pearson correlation coefficient

$* *$ Correlation is significant at the 0.0001 level (2-tailed)

The relationships between self-reported health status and subjective health literacy among young adults. Pursuing to reveal the relationships, young people, who participated in the research, were divided into three groups according to self-reported health status:the first group included people, whose health status was bad/very bad (2.6\%); the second group had fair health $(20.9 \%)$; the third group embraced people with good/very good health $(76.4 \%)$. Having summarised the results (Table 5), it was determined that the young adults characterised by sufficient or excellent levels of health literacy on health care and good/very good self-reported health status, exceeded those with $\mathrm{bad} / \mathrm{very}$ bad or fair health status $\left(\chi^{2}=20.748\right.$; $\left.\mathrm{p}<0.0001\right)$.

The number of the respondents, who demonstrated sufficient or excellent levels of health literacy on disease prevention and who defined their health as good/very good, was bigger than of those, whose health status was bad/very bad or fair $\left(\chi^{2}=32.239 ; \mathrm{p}<0.0001\right)$. Besides, the number of the research participants, who showed sufficient or excellent levels of health literacy on health promotion and good/very good self-reported health status, was also 
greater than the number of those, whose health status was bad/very bad or fair $\left(\chi^{2}=49.119 ; \mathrm{p}<0.0001\right)$. Assessing the relationships of general health literacy with self-reported health status, an analogical tendency was noted $\left(\chi^{2}=35.685\right.$; $\mathrm{p}<0.0001)$.

Table 5 Distribution of young adults by self-reported health status and level of health literacy $(\%)$

\begin{tabular}{|c|c|c|c|c|c|}
\hline & \multirow[b]{2}{*}{$\begin{array}{c}\text { Health } \\
\text { literacy levels }\end{array}$} & \multicolumn{3}{|c|}{ Self-reported health status } & \multirow[b]{2}{*}{$\begin{array}{l}\text { Kruskal-Wallis } \\
\text { Test results }\end{array}$} \\
\hline & & $\begin{array}{c}\text { Bad/ } \\
\text { very bad } \\
(\mathrm{N}=21)\end{array}$ & $\begin{array}{c}\text { Fair } \\
(\mathrm{N}=167)\end{array}$ & $\begin{array}{c}\text { Good/ } \\
\text { very good } \\
(\mathbf{N}=\mathbf{6 1 0}) \\
\end{array}$ & \\
\hline \multirow{4}{*}{$\begin{array}{c}\text { Health } \\
\text { literacy on } \\
\text { health care }\end{array}$} & Inadequate & 28.6 & 28.1 & 17 & \multirow{4}{*}{$\begin{aligned} \chi^{2} & =20.748 \\
p & <0.0001\end{aligned}$} \\
\hline & Problematic & 52.4 & 44.9 & 39.7 & \\
\hline & Sufficient & 14.3 & 21 & 33.4 & \\
\hline & Excellent & 4.8 & 6 & 9.8 & \\
\hline \multirow{4}{*}{$\begin{array}{c}\text { Health } \\
\text { literacy on } \\
\text { disease } \\
\text { prevention }\end{array}$} & Inadequate & 33.3 & 24 & 13 & \multirow{4}{*}{$\begin{aligned} \chi^{2} & =32.239 \\
p & <0.0001\end{aligned}$} \\
\hline & Problematic & 38.1 & 41.9 & 32.8 & \\
\hline & Sufficient & 19 & 28.7 & 37.7 & \\
\hline & Excellent & 9.5 & 5.4 & 16.6 & \\
\hline \multirow{4}{*}{$\begin{array}{c}\text { Health } \\
\text { literacy on } \\
\text { health } \\
\text { promotion }\end{array}$} & Inadequate & 42.9 & 34.7 & 18.2 & \multirow{4}{*}{$\begin{array}{l}\chi^{2}=49.119 \\
p<0.0001\end{array}$} \\
\hline & Problematic & 42.9 & 43.7 & 34.9 & \\
\hline & Sufficient & 9.5 & 19.2 & 34.1 & \\
\hline & Excellent & 4.8 & 2.4 & 12.8 & \\
\hline \multirow{4}{*}{$\begin{array}{c}\text { General } \\
\text { health } \\
\text { literacy }\end{array}$} & Inadequate & 38.1 & 23.4 & 13.8 & \multirow{4}{*}{$\begin{aligned} \chi^{2} & =35.685 \\
p & <0.0001\end{aligned}$} \\
\hline & Problematic & 42.9 & 50.9 & 38.2 & \\
\hline & Sufficient & 14.3 & 23.4 & 39 & \\
\hline & Excellent & 4.8 & 2.4 & 9 & \\
\hline
\end{tabular}

Nevertheless, it should be noted that among the young adults, who described their health status as good or very good, there were people, whose health literacy in three health relevant areas and general health literacy were inadequate or problematic. It is assumed that the limited health literacy will have a negative effect on the changes of the health status of these young people. Moreover, it was determined that the young people, whose health status was $\mathrm{bad} / \mathrm{very}$ bad or fair, were characterised by inadequate or problematic level of health literacy.

\section{Conclusions}

The new conception of health literacy involves abilities to access, understand, appraise and apply information across the domains of health care, disease prevention and health promotion. In scientific literature it is highlighted that health literacy has a great impact on a person's lifestyle and health status. It 
Jurate Cesnaviciene, Stase Ustilaite, Ausra Kalinkeviciene. The Relationships Between SelfReported Health Status and Subjective Health Literacy Among Young Adults in Lithuania

was determined that most Lithuanian young adults (18-29 year old), who participated in the research defined their health status as good or very good. The research revealed that two-fifths of young adults had sufficient or excellent levels of health literacy on health care and health promotion, whereas almost a half of the respondents showed sufficient or excellent levels of health literacy on disease prevention. The results showed high correlation between health literacy in the three health relevant areas and general health literacy. Having generalised the research data, it was noted that the young adults with good/very good selfreported health status tend to achieve sufficient or excellent levels of health literacy on health care, disease prevention or health promotion and general health literacy.

\section{Acknowledgement}

This article was partially supported by the Research Foundation of Lithuanian University of Educational Sciences.

\section{References}

American Medical Association (1999). Health literacy: Report of the Council on Scientific Affairs. Journal of the American Medical Association, 281, 552-557. http://dx.doi.org/10.1001/jama.281.6.552

Berkman, N. D., Sheridan, S. L., Donahue, K. E., Halpern, D. J., \& Crotty, K. (2011). Low health literacy and health outcomes: an updated systematic review. Annals of Internal Medicine, 155, 97-107. http://dx.doi.org/10.7326/0003-4819-155-2-201107190-00005

de Bruin, A., Picavet, H. S., \& Nossikov, A. (1996). Health Interview Surveys: towards international harmonization of methods and instruments. Copenhagen: World Health Organisation. Downloaded from https://extranet.who.int/iris/restricted/bitstream/ 10665/107328/1/E72841.pdf

Dewalt, D. A., Berkman, N. D., Sheridan, S., Lohr, K. N., \& Pignone, M. P. (2004). Literacy and health outcomes: a systematic review of the literature. Journal of General Internal Medicine, 19, 1228-1239. http://dx.doi.org/10.1111/j.1525-1497.2004.40153.x

Grabauskas, V. J., Klumbienė, J., Petkevičienė, J., Šakytė, E., Kriaučionienė, V., \& Veryga, A. (2015). Suaugusių Lietuvos žmonių gyvensenos tyrimas, $2014=$ Health Behaviour among Lithuanian Adult Population, 2014 / Kaunas: Lietuvos sveikatos mokslų universiteto Leidybos namai. Downloaded from http://www.ntakd.lt/ files/Apklausos_ir_tyrimai/nacionalinio/2015/SGT2014.pdf

Health 2020. A European policy framework and strategy for the 21st century (2013). Copenhagen: WHO Regional Office for Europe. Downloaded from http://www.euro.who.int/_data/assets/pdf_file/0011/199532/Health2020-Long.pdf

HLS-EU Consortium (2012). Comparative report of health literacy in eight EU member states. The European Health Literacy Survey HLS-EU. Retrieved from http://www.health-literacy.eu

Javtokas, Z. (2012). Lietuvos gyventojų sveikatos raštingumo tyrimo duomenu apžvalga (In Lithuanian). Downloaded from http://www.smlpc.lt/media/file/SMLPC-informacija/ Veikla/Tyrimai-analizes/Sveikatos\%20rastingumas-2012.pdf 
Lalonde, M. (1974). A new Perspective on the Health of Canadians. Downloaded from http://www.phac-aspc.gc.ca/ph-sp/pdf/perspect-eng.pdf

Mottus, R., Murray, C., Staff, J. M., Johnson, W., Wolf, M. S., \& Deary, I. J. (2014). Towards understanding the links between health literacy and physical health. Health Psychology, 33, 164-173. http://dx.doi.org.ezp.waldenulibrary.org/10.1037/a0031439

Nutbeam, D. (2000). Health literacy as a public health goal: A challenge for contemporary health education and communication strategies into the 21st century. Health Promotion International, 15, 259-267. http://dx.doi.org/10.1093/heapro/15.3.259

Parker, R. M., Baker, D. W., Williams, M. V., \& Nurss, J. R. (1995). The Test of Functional Health Literacy in Adults (TOFHLA): a new instrument for measuring patient's literacy skills. Journal of General Internal Medicine, 10, 537-542. http://dx.doi.org/10.1007/ BF02640361

Sentell, T., Zhang, W., Davis, J., Baker, K. K., \& Braun, K. L. (2014). The Influence of Community and Individual Health Literacy on Self-Reported Health Status. Journal of General Internal Medicine, 29 (2), 298-304. http://doi.org/10.1007/s11606-013-2638-3

Simonds, S. K. (1974). Health education as social policy. Health Education Monograph, 2, 125.

Sørensen, K., van den Broucke, S., Fullam, J., Doyle, G., Pelikan, J., Slonska, Z., \& Brand, H. (2012). Health literacy and public health: A systematic review and integration of definitions and models. BMC Public Health, 12 (1), 80. http://dx.doi.org/10.1186/14712458-12-80

von Wagner, C., Knight, K., Steptoe, A., \& Wardle, J. (2007). Functional health literacy and health-promoting behaviour in a national sample of British adults. Journal of Epidemiology \& Community Health, 61 (12), 1086-1090. http://dx.doi.org/10.1136/ jech.2006.053967

WHO (1998). Health Promotion Glossary. Geneva: World Health Organization. Retrieved from http://apps.who.int/iris/handle/10665/64546

WHO (2015). Health 2020: education and health through the life-course. Downloaded from http://www.euro.who.int/_data/assets/pdf_file/0007/286423/H2020-Sectoral-BriefEducation-health.pdf?ua=1

Williams, M. V., Parker, R. M., Baker, D. W., Parikh, N. S., Pitkin, K., Coates, W. C., \& Nurss, J. R. (1995). Inadequate functional health literacy among patients at two public hospitals. JAMA, 274, 1677-1682. http://dx.doi.org/10.1001/jama.1995. 03530210031026

Zagurskiene, D. (2009). Pacientu sveikatos raštingumo vertinimas: daktaro disertacija: biomedicinos mokslai, slauga (11 B) (In Lithuanian). Kaunas: Kauno medicinos universitetas. Downloaded from http://vddb.laba.lt/obj/LT-eLABa-0001:E.02 2009 D_20090225_131229-37508 